The International Journal of Indian Psychology

ISSN 2348-5396 (e) | ISSN: 2349-3429 (p)

Volume 2, Issue 2, Paper ID: B00358V2I22015

http://www.ijip.in | January to March 2015

\title{
Does Power and Approval Motives Regulate Adolescents' Altruism?
}

\author{
Krishna Kumar Mishra ${ }^{1}$, Jay Singh ${ }^{2}$
}

\section{ABSTRACT:}

The present paper discusses the association of power and approval motives with adolescent altruistic behaviour. Gender difference was also tried to calculate. The present study comprised of 140 students (70 boys and 70 girls) of age range 13-19 years. Participants were given Selfreport Altruism Scale, Power Motive Scale, and Approval Motive Scale. Results indicate that altruism is positively correlated with approval motive and negatively correlated with power motives. Results also revealed significant negative prediction of altruism by Power motive and significantly positively predicted by Approval motive. No gender difference was found in all three variables. Results of the present study will be empirically discussed.

Keywords: Altruism, Power and Approval Motives, Adolescence

\section{INTRODUCTION:}

Anyone wishing to be in power equally requires approval then only altruism can flourish. A recent example of this comes from the widespread protest by citizens across India against corruption. The primary focus of the movement was to ensure a strong Lokpal Bill. The Jan Lokpal Bill (Citizen's Ombudsman Bill) is a draft anti-corruption bill drawn up by prominent civil society activists. The bill can be seen as an altruistic act against corruption. Initially the government by applying power tried to crush the movement. But owing to popular upsurge in favour of Anna Hazare in his fight against corruption, government later bowed and accepted the major demands of team Anna. Thus, to regain the lost approval of people, government finally committed to the enactment of a strong and effective anti-corruption Lokpal bill, giving way to altruism. As in this example, altruism in the human species takes place in a number of contexts and in all known cultures (see, for example, Gouldner, 1960). Any complete list of human altruism would contain the following types of altruistic behavior: (1) helping in times of danger (e.g. accidents, predation, intraspecific aggression; (2) sharing food; (3) helping the sick, the wounded, or the very young and old; (4) sharing implements; and (5) sharing knowledge.

All such forms of behaviour often meet the criterion of small cost to the giver and great benefit to the taker (Trivers, 1971). Psychologically altruistic behaviour may be defined as behaviour that promotes the welfare of others without conscious regards for one's own self -

${ }^{1}$ Post Doctoral Fellow, Department of Psychology, IIT, Kanpur.

${ }^{2}$ Asstt. Professor, Govt. Danteshwari PG College Dantewada (CG).

(C) 2015 I K Mishra, J Singh; licensee IJIP. This is an Open Access Research distributed under the terms of the Creative Commons Attribution License (http://creativecommons.org/licenses/by/2.0), which permits unrestricted use, distribution, and reproduction in any Medium, provided the original work is properly cited. 
-interest (Hoffman, 1978). Psychologists have long assumed that the motivation for all intentional action, including all action intended to benefit others, is egoistic (Batson \& Shaw, 1991). People benefit others because, ultimately, to do so benefits them. We help because we have no choice, because it is expected, or because it is in our own best interest.

We may do a favour to friend because we do not want to lose the friendship or we expect to see the favour reciprocated or at least win the approval. It is always possible when viewing an example of human action that appears to be motivated by an interest in the welfare of the others to, adduce a hidden, or unconscious motive (e.g., social approval, self-esteem) as contributing the real source of such behaviour. Thus the altruism reflects an egoistic motive such as social approval. This is counter indicated, however, by the finding that people are more likely to help when there is no witness present (e.g., Darley \& Latane, 1968). Social approval sometimes acts as a reward that facilitates pro-social behaviour (Deutsch \& Lamberti, 1986).

Crown and Marlowe (1964) have conceptualized approval motive as the desire of individuals to try to achieve favourable evaluations from other member of society. Strickland (1977) has stated that the approval motivated individual responds to his need to gain acceptance, to obtain dependency gratification, and/or status by engaging in approval seeking behaviours in particular situations through positive self presentation and denial of inadequacies. In other words people describe themselves in favourable, socially desirable terms in order to achieve the approval of others.

We would thus expect if approval motive underlie altruistic action, that people tend to help when approval motives are aroused. There should thus be a positive relationship between approval motive and altruism.

Power motive is one of the social motives based on McClelland's theory of human motivation: a concern for impact, which is associated with a need to acquire social status and prestige (McClelland, Davis, Kalin \& Wanner, 1972; McClelland 1975). Power motive refers to individual differences in the human tendency to be dominant and to achieve control over means that can be used to influence other individuals (Veroff, 1957). Striving for status, dominance, superiority, or controlling positions are thus typical of manifestations of the power motive (Winter, 1973).

The motives are thought to tap dispositions and processes operating outside of conscious awareness; therefore, they have been termed "implicit motives" (McClelland, Koestner, \& Weinberger, 1989, p. 690). The motives tend to "predict spontaneous behavioural trends over time" and are expressed in terms of needs like need for Power (n-Power) (McClelland et al., 1989, p. 691; McClelland, 1975). This n-Power can only be satisfied when one is able to make decisions or take actions that affect others' lives (McClelland. 1975; Winter. 1973; Winter, 1992). Although Power typically has been cast in a dark shadow, some have argued that the motivation for power can drive prosocial influence as well (Magee \& Langner, 2008). Need 
for power is thought to have a profound effect on thought and behaviour. Yet, little is known about relationship of power and altruism. But if we dig deeper, understanding whether individuals want to serve others or serve themselves through their influence, we might be able to predict such relationship.

We address this gap in the literature by noting an important relationship that has been lesser investigated in recent research on power motivation. In line with the literature, there should thus be a positive relationship between power motive and altruism.

Recently psychologists have studied altruistic behaviour in order to show what factors induce or inhibit such behaviour. Fewer attempts have been made to show various motives affecting altruistic behaviour. The aim of present study is twofold, it intends to verify empirically whether power and approval, as intrinsic motivation able to crowd out another intrinsic motivation, i.e. altruism, and whether the way in which individuals interact in any context is able to affect each other regarding preferences and the aggregate behaviour of a group of heterogeneous agents. Thus it is worth addressing the question by considering the relationship as well as dependence of altruistic behaviour on two motives, n-Power and n-Approval. Some interesting and recent contributions which analyse similar although different question that is Competition for power and altruism (Bosco, 2009), Does Social Approval Increase Helping? (Deutsch \& Lamberti, 1986), confirm that the issue is of interest and deserves more careful attention.

\section{METHODOLOGY}

\section{Participants}

The present study was carried out with 140 adolescents ( 70 boys and 70 girls) from 13 to 19 year age from different schools of Varanasi District. The participants for the present study were purposively selected from the middle class families; on the basis of family income.

\section{Measures}

\section{Self-report Altruism Scale}

The scale originally developed by Rushton, Chrisjohn and Fekken (1981). Hindi version of Altruism Scale was developed by Khanna, Singh and Rushton (1993). The scale consists of 20 five point Likert type items. The reliability of the scale was found 0.83 and the validity of the scale was reported 0.45 .

\section{Power Motive Scale}

This scale was developed by Dhapola and Singh (1990). The scale consists of 32 Yes-No type items which assesses the overall power motivation of an individual. The test-retest reliability (Chronbach's alpha) of this scale was found 0.72 .

Approval Motive Scale 
This was developed by Tripathi and Tripathi (1980). The scale contains 72 items with three alternatives (Yes, No and Undecided). The test-retest reliability was found .82, and .92 were establish by split-half method.

\section{RESULTS}

Analyses were done on the basis of responses of participants on different measures. Initially we calculated the descriptive nature of data and further we used regression analysis to examine the responses of boys and girls on different scales.

Table 1 presents the mean scores, SD and t-values of total sample on different measures.

Table 1: Descriptive scores and $t$-values of total sample on different measures $(N=140)$

\begin{tabular}{|c|c|c|c|c|c|}
\hline & Gender & N & Mean & S. D. & t-values \\
\hline \multirow{2}{*}{ Altruism } & Male & 70 & 78.29 & 12.15 & \multirow{2}{*}{0.74} \\
\cline { 2 - 5 } & Female & 70 & 76.87 & 10.42 & \\
\hline \multirow{2}{*}{$\begin{array}{c}\text { Power } \\
\text { Motive }\end{array}$} & Male & 70 & 20.24 & 4.49 & \multirow{2}{*}{0.51} \\
\cline { 2 - 5 } & Female & 70 & 19.86 & 4.44 & \\
\hline \multirow{2}{*}{$\begin{array}{c}\text { Approval } \\
\text { Motive }\end{array}$} & Male & 70 & 46.17 & 6.44 & \multirow{2}{*}{1.40} \\
\cline { 2 - 5 } & Female & 70 & 44.36 & 8.64 & \\
\hline
\end{tabular}

Table 1 shows that although boys scored higher on all three variables (altruism, power motive, and approval motive), no significant gender difference was found on any variable; power need $(\mathrm{t}=.51, p>.05)$, approval need $(\mathrm{t}=1.40, p>.05)$ and altruistic behaviour $(\mathrm{t}=.74, p>.05)$.

Table 2 presents the outcomes of linear regression analyses of boys and girls for Power and Approval motives on Altruism measure.

Table 2: Outcome of linear regression analysis for power and approval motives on altruistic behaviour

\begin{tabular}{|c|c|c|c|c|c|}
\hline & \multicolumn{5}{|c|}{ Altruism } \\
\hline Predictors & R & R Square & $\begin{array}{c}\text { Adjusted R } \\
\text { Square }\end{array}$ & F & Beta \\
\hline Approval Motive & .258 & .067 & .060 & $9.87 * *$ & $.258^{* *}$ \\
\hline Power Motive & .172 & .030 & .023 & $4.21^{*}$ & $-.172^{*}$ \\
\hline
\end{tabular}

$* p<.05, * * p<.01$

Results of regression analyses showed significant prediction of power and approval motives for altruistic behaviour. Power motive significantly negatively predicting altruism 
scores, $(\beta=-.172, t(138)=-2.05, p<.05)$. Power motive also explains a significant proportion of variance in altruism score, $R^{2}=.030$ contributing $3.0 \%$ to total variance, $(F(1,139)=4.21, p<$ $.05)$. On the contrary, approval motive significantly positively predicting altruism scores $(\beta=$ $.258, t(138)=3.14, p<.01)$. Approval motive also explains a significant proportion of variance in altruism score, $R^{2}=.067$ contributing $6.7 \%$ to total variance, $(F(1,139)=9.87, p<.01)$.

\section{DISCUSSION}

The main focus of present study was to examine the relationship of power and approval motives with altruistic behaviour of adolescent boys and girls. Though it was hypothesized that both the motives under study bear positive relationships with altruism, data analyses revealed just opposite result of what was assumed in case of power motive. As far as relationship is concerned, power motive found to be negatively related with altruism. Whereas obtained results confirm the proposed positive relationship between approval motive and altruism among adolescents.

Findings of the present study along with other researches evinced that pro-social behaviour increases with increase in approval motive. (Deutsch \& Lamberti, 1986). Analysis also shows that power motive significantly negatively predicts the adolescent's altruistic behaviour. Though there are not sufficient evidences to support this finding, but one of the reasons for obtained negative relationship between power motive and altruism apposite to what was assumed can be attributed to the opposite nature of power and altruism. Power is defined in a very strict sense as "possession of control, authority, or influence over others" (Merrian-Webstair Dictionary); completely underlying self serving belief. Whereas altruism have been subsumed under the general term 'pro-social behaviour' (coined by Wispe' (1972) as a counterpart to 'antisocial behaviour') because they are all aimed, at least in part, at benefiting another individual (Warneken \& Tomasello, 2009).

Analyses of data showed no significant gender difference in any of the variable under study. However, there is mixed evidence on gender differences in altruism from other studies. In a study it was found that, on average, women are predicted to donate more of both money and time (Simmons, \& Emanuele, 2007). Contrary to the finding another study found no significant differences in helping behaviour between male and female subjects (Monk-Turner et. al, 2002). In support to this finding, Eagly and Crowley's (1986) social role theory maintains that the traditional male sex role promotes heroic and chivalrous helping behaviour. Previous studies and original research on the power motive (n Power) in women show no sex differences in the ways in which the power motive is aroused (Winter, 1988). Thus in case of Power motive, the obtained result confirms earlier findings asserting no gender difference in power motive.

Regression analysis showed that power motive significantly negatively predicts the adolescent's altruistic behaviour, whereas approval motive significantly positively predicts their altruistic behaviour. These findings reveals that power and approval motives are imperative predictor of 
altruistic behaviour and balance of both motives are must for enhancing altruism. Therefore adolescents can consciously change the directions of their need for power so that proper blend of n-power and n-approval aroused, then only feelings of altruism can flourish. Clearly, altruism is not simply a matter of how powerful one is, but of how capable one be in gaining approval from others too.

\section{REFERENCES}

Batson, C. D., \& Shaw, L. L. (1991). Evidence for altruism: Toward a pluralism of prosocial motives. Psychological Inquiry, 2(2), 107-122.

Bosco, L. (2009). Competition for power and altruism . Dipartimento di Economia Politica, Università di Siena.

Crowne, D. P., \& Marlowe, D. (1964). The approval motive: Studies in evaluative dependence. New York: Wiley.

Darley, J. M., \& Latane, B. (1968). Bystander intervention in emergencies: Diffusion of responsibility. Journal of Personality and Social Psychology, 8, 377-383.

Deutsch, F. M., \& Lamberti, D. M. (1986). Does social approval increase helping? Personality and Social Psychology Bulletin, 12(2), 149-157.

Dhapola, T. S., \& Singh, G. (1990). Power motivation scale. Published by Manovaigyanik Parikshan Sansthan, Varanasi, India.

Eagly, A., \& Crowley, M. (1986). Gender and helping behaviour: A meta-analytical review of the social psychological literature. Psychology Bulletin, 100, 283-308.

Gouldner, A. (1960). The norm of reciprocity: A preliminary statement. American Sociological Review, 47, 73-80.

Khanna, R., Singh, P., \& Rushton, J. P. (1993). Development of the Hindi version of a self-report altruism scale. Personality and Individual differences, 14, 267-270.

McClelland, D. C. (1975). Power: The inner experience. New York: Irvington.

McClelland, D. C., Davis, W. N., Kalin, R., \& Wanner, E. (1972). The drinking man. New York: Free Press.

McClelland, D. C., Koestner, R., \& Weinberger, J. (1989). How do self-attributed and implicit motives differ? Psychological Review, 96, 690-702.

Monk-Turner, E., Blake, V., Chniel, F., Forbes, S., Lensey, L., \& Madzuma, J. (2002). Helping hands: A study of altruistic behaviour. Gender Issues, 20, 65-70.

Rushton, J. P., Chrisjohn, R. D., \& Fekken, G. L. (1981). The altruistic personality and the selfreport altruism scale. Personality and Individual Differences, 2, 293-302.

Simmons, W. O., \& Emanuele, R. (2007). Male-female giving differentials: Are women more altruistic? Journal of economic studies, 34(6)534-550. 
Strickland, B. (1977). Approval motivation. In T. T. Blass (Eds.) Personality variables in social Behaviour (pp. 317-356), Hillside New Jersy: Lawrence Erlbaum Associates.

Tripathi, N. K. M., \& Tripathi, L. B. (1980). Approval motive scale. Published by National Psychological Corporation, Agra, India.

Trivers, R. L. (1971). The evolution of reciprocal altruism. The Quarterly Review of Biology, $46(1), 35-57$.

Veroff, J. (1957). Development and validation of a projective measure of power motivation. Journal of Abnormal and Social Psychology, 54, 1-8.

Warneken, F., \& Tomasello, M. (2009). The roots of human altruism. British Journal of Psychology, 100, 455-471.

Winter, D. G. (1973). The power motive. New York: The Free Press.

Winter, D. G. (1992). Power motivation revisited. In C. P. Smith (Eds.), Motivation and personality: Handbook of thematic content analysis (pp. 301-310). Cambridge, UK:Cambridge University Press.

Winter, D. G. (1988). The power motive in women- and men. Journal of Personality and Social Psychology, 54(3), 510-519.

Wispe, L. G. (1972). Positive forms of social behaviour: An overview. Journal of Social Issues, 28(3), 1-19. 